\title{
Haematological and spermatotoxic effects of ethylene glycol monomethyl ether in copper clad laminate factories
}

Tung-Sheng Shih, An-Tsz Hsieh, Guo-Dong Liao, Yeong-Hwang Chen, Saou-Hsing Liou

\begin{abstract}
Objectives-To investigate the effects of ethylene glycol monomethyl ether (EGME) on haematology and reproduction in exposed workers.

Methods-53 Impregnation workers from two factories that make copper clad laminate with EGME as a solvent were recruited as the exposed group. Another group of 121 lamination workers with indirect exposure to EGME was recruited as the control group. Environmental monitoring of concentrations of EGME in air and biological monitoring of urinary methoxyacetic acid (MAA) concentrations were performed. Venous blood was collected for routine and biochemical analyses. Semen was collected from 14 workers exposed to EGME for sperm analysis and was compared with 13 control workers.
\end{abstract}

Results-Results of haematological examination showed that the haemoglobin, packed cell volume, and red blood cell count in the male workers exposed to EGME were significantly lower than in the controls. The frequency of anaemia in the exposed group $(26.1 \%)$ was significantly higher than in the control group (3.2\%). However, no differences were found between the female workers exposed and not exposed to EGME. After adjustment for sex, body mass index, and duration of employment, red blood cell count was significantly negatively associated with air concentrations of EGME, and haemoglobin, packed cell volume, and red blood cell count were significantly negatively associated with urinary concentrations of MAA. The pH of semen in the exposed workers was significantly lower than in the control workers, but there were no significant differences in the sperm count or sperm morphology between the exposed and control groups.

Conclusion-It can be concluded that EGME is a haematological toxin, which leads to anaemia in the exposed workers. However, the data from this study did not support the theory of a spermatotoxic effect of EGME.

(Occup Environ Med 2000;57:348-352)

Keywords: ethylene glycol monomethyl ether; haematological disorders; spermatotoxicity
Ethylene glycol monomethyl ether (EGME, $\mathrm{CH}_{3} \mathrm{OCH}_{2} \mathrm{CH}_{2} \mathrm{OH}$, 2-methoxyethanol, 2-ME), one of many derivatives of ethylene glycol ethers (EGEs), is a volatile and almost odourless liquid. It has been commercially available for the past 4 decades and is used primarily as an industrial solvent for resins, lacquers, and paints. ${ }^{1}$

The annual production rate for EGEs was estimated to be about $200000000 \mathrm{~kg}$ with $40000000 \mathrm{~kg}$ being EGME in the United States. ${ }^{1}$ It was also estimated that at least 140000 workers are exposed to it. As EGME is rarely used in consumer products, it can be assumed that most citizens are not exposed to EGME. About 2500-3000 tonnes of EGME are imported and used in Taiwan annually, ${ }^{2}$ about $90 \%$ in the coating industry. Lack of recognition of the potentially toxic effects in Taiwanese workers was noted and the possibility of skin absorption was found to be common among EGME users.

Overexposure to EGME has been shown to cause toxic effects. Subacute and chronic overexposure in humans through inhalation or percutaneous absorption has been associated with various haematological abnormalities, oligospermia, and toxic encephalopathy. ${ }^{1}$ The objective of this study was to investigate the haematological and spermatotoxic effects among workers after exposure to EGME in two factories manufacturing copper clad laminate in Taiwan.

\section{Materials and methods}

MANUFACTURING PROCESSES

The usual operations in the manufacture of copper clad laminate include mixing, implantation, drying, cutting, lamination, trimming, and inspection. The main raw materials used in these plants include epoxy and phenolic resins, hardener (dicyanamide), catalyst (2-methylimidazole), antimony oxide, aluminum oxide, silica dioxide, titanium oxide, pigments, acetone, and EGME. The EGME and acetone are the only two volatile chemicals used in the workplace. The solvent of coating glue contains $70 \%$ EGME and $30 \%$ acetone.

\section{STUDY POPULATION}

Workers from two factories manufacturing copper clad laminate were selected as the study population. All participants gave informed consent. All 53 workers from the departments of mixing, implantation, drying, and cutting, with potentially direct exposure to EGME, were recruited as the exposed group. Another 121 lamination workers with indirect exposure to EGME were selected as controls. 
Table 1 The distribution of characteristics among the study population

\begin{tabular}{|c|c|c|c|}
\hline Variables & Exposed $(n=53)$ & $\begin{array}{l}\text { Comparison } \\
(n=121)\end{array}$ & $p$ Value \\
\hline Age (y, mean (SD)) & $29.89(7.25)$ & $29.58(7.55)$ & 0.86 \\
\hline Duration of employment (y, mean (SD)) & $2.60(2.90)$ & $3.58(2.82)$ & 0.03 \\
\hline Body mass index $\left(\mathrm{kg} / \mathrm{m}^{2}\right.$, mean $\left.(\mathrm{SD})\right)$ & $23.81(5.31)$ & $22.45(3.41)$ & 0.04 \\
\hline Sex (male, n (\%)) & $47 \quad(88.7)$ & $(76.0)$ & 0.03 \\
\hline Marital status (single, $\mathrm{n}(\%)$ ) & $(43.4)$ & $(47.9)$ & 0.36 \\
\hline Smoking status (smoker, $\mathrm{n}(\%)$ ) & $(60.4)$ & $(66.1)$ & 0.50 \\
\hline
\end{tabular}

DATA COLLECTION

Questionnaires were used to collect personal characteristics, personal habits-for example, alcohol drinking and smoking-reproductive history, detailed occupational history, and related symptoms.

\section{ENVIRONMENTAL MONITORING}

The United States NIOSH 1403 and OSHA 79 sampling and analytical methods were adopted in this study. Briefly, the 8 hour time weighted averaged personal breathing zone air samples were collected by drawing air through standard size coconut shell charcoal tubes (SKC 226-01, PA, USA) with constant low flow personal pumps (Gilian, Model LFS-114, FL, USA). The charcoal was then desorbed in $1 \mathrm{ml}$ mixed solvent of 95:5 (v/v) dichloromethane and methanol. After 40 minutes of shaking, the desorbed EGME was analysed with a gas chromatograph (Hewlett-Packard 5890 Series II, CA, USA) equipped with an HP 7673A autosampler and a flame ionisation detector (FID). The detailed analytical procedures have been described elsewhere. ${ }^{3}$

\section{BIOLOGICAL MONITORING}

Spot urine samples were collected from each worker for EGME metabolite measurement. Urinary methoxyacetic acid (MAA) was measured with a modified method previously reported by Sakai et al. ${ }^{4}$ This method was fully approved by the Institute of Occupational Safety and Hygiene (IOSH), Taiwan and two other reference laboratories before it was adopted in this study. The detailed procedures have been described elsewhere. ${ }^{5}$

\section{MEDICAL EXAMINATION}

About $10 \mathrm{ml}$ blood was collected from each worker for haematological and biochemical examinations. Sperm was collected from 14 exposed and 13 control volunteers for sperm counts and morphological examinations. The motility of sperm was not used in this report due to the lag time between collection and examination being $>1$ hour.

STATISTICAL ANALYSIS

Student's $t$ test and $\chi^{2}$ test were used to compare the differences between the exposed and control groups. A test for equality of variance was performed for Student's $t$ test and adjusted variance and degree of freedom were applied if the variances were not equal. Due to the small sample size, the comparitive statistical analysis of sperm was performed with the non-parametric Mann-Whitney $U$ test.

After identification of potential confounders, multiple linear regression was used to examine the net effects of exposure to EGME. Multiple linear regression was also used to evaluate the dose-response relation between concentrations of EGME in air or urinary concentrations of MAA and haematological outcomes.

\section{Results}

ENVIRONMENTAL AND BIOLOGICAL MONITORING DATA

The geometric mean air concentration of EGME in the impregnation area was 3.98 ppm (SD 2.88, $\mathrm{n}=55$ personal samples), with a maximum of $30.07 \mathrm{ppm}$ and minimum of 0.65 ppm in one factory. The air concentration of EGME in another factory was 4.27 ppm (SD) $2.19, \mathrm{n}=11$ personal samples), with a maximum of $20.00 \mathrm{ppm}$ and a minimum of 1.70 ppm. The range of EGME concentrations in the lamination area (control group, $n=9$ ) was between non-detectable and $0.28 \mathrm{ppm}$. Although the mean concentration was not over the permissible exposure limit of $5 \mathrm{ppm}$, some workers, especially impregnation and mixing workers, were exposed to high concentrations of EGME.

The geometric mean urinary concentration of MAA in workers from the impregnation area was $19.95 \mathrm{mg} / \mathrm{g}$ creatinine (SD 2.19, $\mathrm{n}=30$ ) in one factory and $20.89 \mathrm{mg} / \mathrm{g}$ creatinine (SD $2.19, \mathrm{n}=15$ ) in another factory, ranging from non-detectable to $65.88 \mathrm{mg} / \mathrm{g}$ creatinine. The MAA concentration of lamination control workers $(\mathrm{n}=32)$ was $1.26 \mathrm{mg} / \mathrm{g}$ creatinine (SD

Table 2 Comparison of mean (SD) results of haematological tests among male workers exposed and not exposed to EGME

\begin{tabular}{|c|c|c|c|c|c|c|}
\hline \multirow[b]{2}{*}{ Items } & \multicolumn{3}{|l|}{ Male } & \multicolumn{3}{|l|}{ Female } \\
\hline & $\begin{array}{l}\text { Exposed group } \\
(n=46)\end{array}$ & $\begin{array}{l}\text { Comparison } \\
\text { group }(n=93)\end{array}$ & $p$ Value ${ }^{\star}$ & $\begin{array}{l}\text { Exposed group } \\
(n=5)\end{array}$ & $\begin{array}{l}\text { Comparison group } \\
(n=28)\end{array}$ & $p$ Value ${ }^{\star}$ \\
\hline Haemoglobin $(\mathrm{g} / \mathrm{dl})$ & $14.43(1.78)$ & $15.50(1.06)$ & $<0.001$ & $12.90(2.60)$ & $12.53(1.16)$ & 0.77 \\
\hline Packed cell volume (\%) & $43.33(5.00)$ & $47.81(3.10)$ & $<0.001$ & $39.40(7.16)$ & $40.43(3.05)$ & 0.59 \\
\hline Red blood cells $\left(10^{6} / \mu \mathrm{l}\right)$ & $4.73(0.64)$ & $5.37(0.54)$ & $<0.001$ & $4.18(0.78)$ & $4.71(0.56)$ & 0.07 \\
\hline \multicolumn{7}{|l|}{ White blood cells } \\
\hline$\left(10^{3} / \mu \mathrm{l}\right)$ & $7.17(2.11)$ & $7.08(1.80)$ & 0.81 & $7.90(5.03)$ & $6.26(1.53)$ & 0.51 \\
\hline Neutrophil $\left(10^{3} / \mu \mathrm{l}\right)$ & $4.36(1.71)$ & $4.46(1.41)$ & 0.75 & $5.60(4.26)$ & $3.96(1.20)$ & 0.44 \\
\hline Lymphocyte $\left(10^{3} / \mu \mathrm{l}\right)$ & $2.45(0.77)$ & $2.24(0.540$ & 0.09 & $1.95(0.75)$ & $1.95(0.46)$ & 0.99 \\
\hline Platelet $\left(10^{3} / \mu \mathrm{l}\right)$ & $271.00(66.66)$ & $249.86(58.88)$ & 0.06 & $257.60(65.92)$ & $256.14(71.33)$ & 0.97 \\
\hline $\operatorname{MCV}(\mathrm{fl})$ & $92.14(6.02)$ & $89.66(7.45)$ & 0.052 & $94.50(4.61)$ & $86.83(10.37)$ & 0.12 \\
\hline $\mathrm{MCH}(\mathrm{pg})$ & $30.65(2.05)$ & $29.71(6.58)$ & 0.35 & $30.90(2.21)$ & $26.94(3.75)$ & 0.03 \\
\hline $\mathrm{MCHC}(\mathrm{g} / \mu \mathrm{l})$ & $33.27(5.90)$ & $33.10(6.64)$ & 0.86 & $32.67(1.13)$ & $30.96(1.20)$ & 0.006 \\
\hline
\end{tabular}

^Student's $t$ test.

Abbreviation: $\mathrm{MCV}=$ mean corpuscular volume; $\mathrm{MCH}=$ mean corpuscular haemoglobin; $\mathrm{MCHC}=$ mean corpuscular haemoglobin concentration. 
Table 3 The distribution of abnormal haematological test results among male workers exposed and not exposed to EGME

\begin{tabular}{|c|c|c|c|}
\hline Items & $\begin{array}{l}\text { Exposed } \\
n(\%)\end{array}$ & $\begin{array}{l}\text { Not exposed } \\
n(\%)\end{array}$ & $p$ Value * \\
\hline Haemoglobin (g/dl) & & & 0.0001 \\
\hline Abnormal $(<13.5)$ & $12(26.1)$ & $3(3.2)$ & \\
\hline Normal $(\geqslant 13.5)$ & $34(73.9)$ & $90(96.8)$ & \\
\hline Packed cell volume (\%) & & & $<0.0001$ \\
\hline Abnormal $(<40)$ & $10(21.7)$ & $0(0)$ & \\
\hline Normal $(\geqslant 40)$ & $36(78.3)$ & $93(100)$ & \\
\hline Red blood cells $\left(10^{6} / \mu \mathrm{l}\right)$ & & & $<0.0001$ \\
\hline Abnormal $(<4.5)$ & $13(28.3)$ & $3(3.2)$ & \\
\hline Normal $(\geqslant 4.5)$ & $33(71.7)$ & $90(96.8)$ & \\
\hline White blood cells $\left(10^{3} / \mu \mathrm{l}\right)$ & & & 0.85 \\
\hline Abnormal $(<5.0)$ & $7(15.2)$ & $13(14.0)$ & \\
\hline Normal $(\geqslant 5.0)$ & $39(84.8)$ & $80(86.0)$ & \\
\hline Platelets $\left(10^{3} / \mu \mathrm{l}\right)$ & & & 0.45 \\
\hline Abnormal $(<150)$ & $0(0)$ & $2(2.2)$ & \\
\hline Normal $(\geqslant 150)$ & $46(100)$ & $91(97.8)$ & \\
\hline
\end{tabular}

Table 4 The multiple regression model of the concentration of EGME in air on haematological effects $(n=40)$

\begin{tabular}{llccc}
\hline Dependent variables & Independent variables & Coefficient & $S D$ & p Value \\
\hline Haemoglobin & Constant & 7.43 & & - \\
& Sex & -0.79 & 0.81 & 0.34 \\
& BMI & 0.34 & 0.09 & $<0.001$ \\
& Work-year & -0.004 & 0.12 & 0.98 \\
Packed cell volume & Log (air EGME) & -0.14 & 0.39 & 0.71 \\
& Constant & 25.75 & & - \\
& Sex & -1.02 & 2.39 & 0.67 \\
& BMI & 0.88 & 0.26 & 0.003 \\
Work-year & 0.027 & 0.36 & 0.87 \\
& Log (air EGME) & -1.59 & 1.15 & 0.18 \\
& Constant & 4.00 & & - \\
& Sex & -0.38 & 0.33 & 0.27 \\
& BMI & 0.062 & 0.04 & 0.10 \\
White blood cells & Work-year & 0.011 & 0.05 & 0.82 \\
& Log (air EGME) & -0.51 & 0.16 & 0.004 \\
& Constant & 4.38 & & - \\
& Sex & -1.13 & 0.93 & 0.24 \\
& BMI & 0.16 & 0.10 & 0.12 \\
Work-year & -0.069 & 0.14 & 0.63 \\
& Log (air EGME) & -0.16 & 0.45 & 0.72 \\
& Constant & 252.87 & & - \\
& Sex & -39.49 & 30.21 & 0.20 \\
& BMI & 3.51 & 3.29 & 0.30 \\
& Work-year & -2.41 & 4.53 & 0.60 \\
& Log (air EGME) & -15.42 & 14.56 & 0.30 \\
\hline
\end{tabular}

Table 5 The multiple regression model of concentration of $M A A$ in urine on haematological effects $(n=62)$

\begin{tabular}{|c|c|c|c|c|}
\hline Dependent variables & $\begin{array}{l}\text { Independent } \\
\text { variables }\end{array}$ & Coefficient & $S D$ & $p$ Value \\
\hline \multirow[t]{5}{*}{ Haemoglobin } & Constant & 15.52 & & - \\
\hline & Sex & -2.37 & 0.46 & $<0.001$ \\
\hline & $\mathrm{BMI}$ & 0.11 & 0.07 & 0.11 \\
\hline & Work-year & -0.041 & 0.07 & 0.57 \\
\hline & $\log (\mathrm{MAA} / \mathrm{Cr})$ & -0.93 & 0.30 & 0.003 \\
\hline \multirow[t]{5}{*}{ Packed cell volume } & Constant & 47.50 & & - \\
\hline & Sex & -5.79 & 1.26 & $<0.001$ \\
\hline & BMI & 0.27 & 0.18 & 0.14 \\
\hline & Work-year & -0.080 & 0.20 & 0.69 \\
\hline & $\log (\mathrm{MAA} / \mathrm{Cr})$ & -3.70 & 0.82 & $<0.001$ \\
\hline \multirow[t]{5}{*}{ Red blood cells } & Constant & 5.42 & & - \\
\hline & Sex & -0.43 & 0.17 & 0.01 \\
\hline & $\mathrm{BMI}$ & 0.015 & 0.02 & 0.54 \\
\hline & Work-year & 0.016 & 0.03 & 0.54 \\
\hline & $\log (\mathrm{MAA} / \mathrm{Cr})$ & -0.57 & 0.11 & $<0.001$ \\
\hline \multirow[t]{5}{*}{ White blood cells } & Constant & 3.09 & & - \\
\hline & Sex & 0.44 & 0.58 & 0.45 \\
\hline & BMI & 0.15 & 0.08 & 0.07 \\
\hline & Work-year & -0.14 & 0.09 & 0.14 \\
\hline & $\log (\mathrm{MAA} / \mathrm{Cr})$ & 0.25 & 0.38 & 0.51 \\
\hline \multirow{5}{*}{ Platelets } & Constant & 207.29 & & - \\
\hline & Sex & 33.08 & 18.71 & 0.08 \\
\hline & BMI & 0.42 & 2.69 & 0.88 \\
\hline & Work-year & -2.43 & 2.98 & 0.42 \\
\hline & $\log (\mathrm{MAA} / \mathrm{Cr})$ & 14.07 & 12.21 & 0.25 \\
\hline
\end{tabular}

$\mathrm{MAA} / \mathrm{Cr}=\mathrm{MAA} \mathrm{mg} / \mathrm{g}$ creatinine.
1.62), ranging from non-detectable to 4.22 $\mathrm{mg} / \mathrm{g}$ creatinine.

DISTRIBUTION OF CHARACTERISTICS AMONG STUDY SUBJECTS

The distribution of characteristics among study subjects is listed in table 1 . There were no differences between the exposed and control groups in the distribution of age, marital status, or smoking. However, the distribution of sex, body mass index (BMI), and duration of employment was significantly different between these two groups. The control group had longer duration of employment, lower BMI, and more female workers. As sex may be a confounder, the analysis in this study was stratified by sex.

\section{HAEMATOLOGICAL EFFECTS}

The result of haematological examinations stratified by sex is shown in table 2 . There was a significantly lower count of haemoglobin, packed cell volume, and red blood cells in exposed male workers than in control male workers, however, there were no significant differences among the female workers. There were no haematological differences in the white blood cell or platelet counts.

The cut off points of male abnormal values for haemoglobin, packed cell volume, red blood cell count, white blood cell count, and platelets were set at $13.5 \mathrm{~g} / \mathrm{dl}, 40 \%, 4.5$ million $/ \mu 1,5000 / \mu 1$, and $150000 / \mu 1$, respectively. The distribution of abnormal values in male workers is shown in table 3 . The proportions of abnormal values in haemoglobin, packed cell volume, and red blood cell count in exposed male workers were significantly higher than in control male workers.

DOSE-RESPONSE RELATION BETWEEN EXPOSURE TO EGME AND HAEMATOLOGICAL EFFECTS The multiple regression model of concentration of EGME in air on haematological variables is shown in table 4 . Red blood cell count was significantly associated with concentration of EGME in air. The higher the concentration of EGME, the lower the red blood cell count. However, the negative coefficients of haemoglobin and packed cell volumes were not significantly associated with the concentration of EGME in air.

The multiple regression model of concentration of urinary MAA on haematological variables is shown in table 5. Haemoglobin, packed cell volume, and red blood cell count were significantly negatively associated with urinary MAA. Both environmental and biological monitoring data indicated a negative dose-response relation between exposure to EGME and red blood cell damage.

SPERMATOTOXIC EFFECTS

The result of sperm analyses is shown in table 6. Except for the $\mathrm{pH}$ value, there were no significant differences between the exposed and control workers. The mean $\mathrm{pH}$ value in the exposed workers was significantly lower than in the control workers. 
Table 6 The results (mean (SD)) of sperm analysis among workers exposed and not exposed to EGME

\begin{tabular}{llll}
\hline Items & $\begin{array}{l}\text { Exposed group } \\
n=14\end{array}$ & $\begin{array}{l}\text { Comparison group } \\
n=13\end{array}$ & $p$ Value \\
\hline Volume $(\mathrm{ml})$ & $3.68(3.02)$ & $3.65(1.75)$ & 0.98 \\
pH & $7.08(0.29)$ & $7.51(0.43)$ & 0.005 \\
Sperm count $\left(10^{6} / \mathrm{ml}\right)$ & $51.89(3.14)$ & $50.08(2.40)$ & 0.93 \\
Morphology (normal, \%) & $87.14(2.57)$ & $86.15(3.63)$ & 0.42 \\
\hline
\end{tabular}

*Mann-Whitney $U$ test.

\section{Discussion}

Ethylene glycol ethers (including ethylene glycol ether esters (EGEs)) are a group of solvents with medium high boiling points and low evaporation rates. Ethylene glycol monomethyl ether, one of many derivatives of ethylene EGEs, is a volatile and almost odourless liquid. It has been commercially available for the past 4 decades and is used primarily as an industrial solvent for coating materials. ${ }^{1}$ Data from a hazard survey showed that large amounts of $\mathrm{E}$ series EGEs are imported and used in Taiwan. Our estimates are : EGME 2500-3000 tonnes, ethylene glycol monoethyl ether (EGEE) 1200-1800 tonnes, ethylene glycol monoethyl ether acetate (EGEEA) 5000-8000 tonnes, and ethylene glycol monobutyl ether (EGBE) $8000-10000$ tonnes annually. About $90 \%$ is used in the coating industries - that is, in the manufacture or use of paint, thinner, and ink, and EGME is used especially in the copper clad laminate manufacturing industry. ${ }^{2}$

The main route of entry into factory workers is inhalation, but skin absorption is often overlooked. Lack of recognition of the potential toxic effects of these chemicals was noted ${ }^{6}$ and the potentially toxic effects from skin absorption are common among the workers. Recently, low molecular weight $\mathrm{E}$ series glycol ethers (including EGME, EGMEA, EGEE, and EGEEA) have been found to have haematological, reproductive and teratogenic toxicity. ${ }^{1}$ This study showed similar haematological toxicity (specifically erythropoietic), but no reproductive toxic effects among workers exposed to EGMEs.

As well as encephalopathy and neurological disorders, ${ }^{7}$ haematological disorders were the most commonly reported effects. The haematological toxicity of EGME includes leukopenia, lymphocytosis, pancytopenia, marrow depression, and decreased red blood cell count, haemoglobin, and platelet count. ${ }^{6-11}$ Parsons and Parsons ${ }^{7}$ reported two patients with EGME intoxication in "fused collar" workers. Both patients presented with severe anaemia with leukopenia and lymphocytosis. Groetschel and Schuermann ${ }^{8}$ reported one patient with EGME intoxication in a small printing shop, who presented with anaemia and lymphopaenia. Zovon ${ }^{9}$ reported five workers in the printing department of a plastic plant who had low red blood cell counts and low haemoglobin values, but white blood cell counts ranged from low to high. Cohen ${ }^{10}$ reported a worker in a microfilm production factory with 9 months of exposure to EGME who developed macrocytic anaemia and mild leukopenia. Larese et $a l^{11}$ reported a frame worker who presented with macrocytic anaemia and leukopenia after exposure to EGME. However, the patient's abnormalities returned to normal after EGME exposure stopped.

As well as the case reports of haematological effects of EGME intoxication, several epidemiological investigations were conducted to elaborate the haematological toxicity. Greenburg et al found that 19 workers exposed to high concentrations of EGME during the manufacture of fused shirt collars had abnormal haematology results. ${ }^{12}$ Nine of the workers' blood tests showed disturbed erythropoiesis including six subnormal red blood cell counts. The anaemias were thought to be caused by a bone marrow toxin rather than haemolysis or peripheral toxicity. Cook et al investigated the haematological effects among 65 workers in EGME manufacturing and packing with very low exposures, but no significant abnormalities were found. ${ }^{13} \mathrm{~A}$ cross sectional study of shipyard painters exposed to a mean (SD) EGME concentration of $0.8(1.0) \mathrm{ppm}$, and a mean EGEE concentration of 2.6 (4.2) ppm, found a higher proportion of anaemia (haemoglobin $<14 \mathrm{~g} / \mathrm{dl}$ ) in the painters than in the non-exposed workers, but the mean values of haemoglobin and other haematological indicators were not different between exposed and non-exposed workers. ${ }^{14}$ Our study also indicated a higher proportion of anaemia and lower mean haemoglobin, packed cell volume, and red blood cell counts in the group exposed to EGME than in the control group. However, the white blood cell and platelet counts were not lower in the exposed group. These findings are consistent with previous studies that show that high exposure of EGME will induce haematological defects. Haematological disorders induced by exposure to EGME have also been confirmed in animal studies. The haematological toxicity in animals included decreased concentrations of haemoglobin and packed cell volume, decreased white and red blood cell counts, reduced bone marrow cellularity, and reduced erythropoiesis and haemolysis.

The toxic effects on animals also included male reproduction. The animals exposed to EGME showed testicular atrophy, abnormal sperm morphology, degeneration of late spermatocytes and spermatids, decreased numbers of sperm, and increased numbers of immature germ cells, decreased sperm motility, peritubular membrane damage, and germinal epithelial distortion of the seminiferous epithelium. ${ }^{15-17}$ There are few published studies on the effects on human reproduction. ${ }^{13}{ }^{18}$ Cook et al studied six workers exposed to EGME and nine controls. ${ }^{13}$ The size of the testes was smaller in the workers exposed to EGME than in the control workers, but the sperm count was not different between these two groups. Welch et al studied shipyard painters and found the proportions of oligospermia and azoospermia were non-significantly higher in the painters than in the non-exposed workers. ${ }^{18}$ Also, the semen $\mathrm{pH}$ was significantly lower in the exposed group, but the sperm morphology and motility were not significantly different. Our study also found that there were no differences 
in sperm count or morphology, except for lower sperm $\mathrm{pH}$ in the exposed group.

Based on the potential toxicity of EGEs, the American Conference of Governmental Industrial Hygienists adopted a new EGME threshold limit value of $5 \mathrm{ppm}$ in 1984; Germany, Japan, and Sweden also lowered their exposure standards in 1986, 1990, and 1991, respectively. As a result, most of the manufacturers of EGEs have also taken action to stop the production and sale of these potentially hazardous products. Thus, occupational health education, modification of current legislation, and provision for substitutes are urgently needed.

This study was supported in part by Institute of Occupationa Safety and Health, Council of Labor Affairs, the Executive Yuan, Republic of China.

1 National Institute for Occupational Safety and Health. Criteria for a recommended standard: Occupational exposure to ethylene glycol monomethyl ether, ethylene glycol monoethyl ethe and their acetates. Cincinatti: US Department of Health and Human Service, Centers for Disease Control, NIOSH, 1992.

2 Lin CK, Chen RY. Survey of glycol ether use in Taiwan, 1991. Am ₹ Ind Med 1993;24:101-8.

3 Shih TS, Chen CY, Cheng RI, et al. Exposure assessment of 2-methoxy ethanol. The Ninth Annual Conference of the International Society for Environmental Epidemiology, August national Society for Environmental Epidemiology, August 17-20, Academia Sinica International

4 Sakai T, Araki T, Masuyama Y. Determination of urinary alkoxyacetic acids by a rapid and simple method for alkoxyacetic acids by a rapid and simple method for
biological monitoring of workers exposed to glycol ethers and their acetates. Int Arch Occup Environ Health 1993;64 $495-8$
5 Shih TS, Chou JS, Chen CY, et al. Improved method to measure urinary alkoxyacetic acids. Occup Environ Med 1999;56:460-7.

6 Ohi G, Wegman DH. Transcutaneous ethylene glycol monomethyl ether poisoning in the work setting. $\mathcal{F}$ Occup Med 1978;20:675-6.

7 Parsons CE, Parsons ME. Toxic encephalopathy and granulopenic anemia due to volatile solvents in industry: report of two cases. F Ind Hyg Toxicol 1938;20:124-33.

8 Groetschel H, Schuermann D. Mass toxic effects in printing works where ethylene glycol monomethyl ether was used as a solvent. Arch Toxicol 1959;17:243-51.

9 Zavon MR. Methyl cellosolve intoxication. Am Ind Hyg Assoc f 1963;24:36-41.

10 Cohen R. Reversible subacute ethylene glycol monomethyl ether toxicity associated with microfilm production: a case report. Am $\mathcal{F}$ Ind Med 1984;6:441-6.

11 Larese F, Fiorito A, Zotti RD. The possible haematological effects of glycol monomethyl ether in a frame factory. $\mathrm{Br} \mathcal{F}$ Ind Med 1992;49:131-3.

12 Greenburg L,Mayers MR,Goldwater LJ, et al. Health hazards in the manufacturer of fused collars: I. Exposure to ethylene glycol monomethyl ether. F Ind Hyg Toxicol 1938; 20:134-47.

13 Cook RR, Vanpeenen PFD, Bodner KM, et al. A cross sectional study of ethylene glycol monomethyl ether process employees. Arch Environ Health 1982;37:346-51.

14 Welch LS, Cullen MR. Effects of exposure to ethylene glycol ethers on shipyard painters: III. Hematologic effects. Am $\mathcal{F}$ Ind Med 1988;14:517-36.

15 Anderson D, Brinkworth MH, Jenkinson PC, et al. Effect of ethylene glycol monomethyl ether on spermatogenesis, dominant lethality, and $\mathrm{F}_{1}$ abnormalities in the rat and the mouse after treatment of $F_{0}$ males. Teratog Carcinog Mutagen 1987;7:141-58

16 Creasy DM, Foster PMD. The morphological development of glycol ether-induced testicular atropy in the rat. $\operatorname{Exp~Mol}$ Pathol 1984;40:169-76.

17 Miller RR, Ayres JA, Young JT, et al. Ethylene glycol monomethyl ether. I. Subchronic vapor inhalation study with rats and rabbits. Fund Appl Toxicol 1983;3:49-54.

18 Welch LS, Schrader SM, Turner TW, et al. Effects of exposure to ethylene glycol ethers on shipyard painters: II. male reproduction. Am F Ind Med 1988;14:509-26.

\section{Correspondence and editorials}

Occupational and Environmental Medicine welcomes correspondence relating to any of the material appearing in the journal. Results from preliminary or small scale studies may also be published in the correspondence column if this seems appropriate. Letters should be not more than 500 words in length and contain a minimum of references. Tables and figures should be kept to an absolute minimum. Letters are accepted on the understanding that they be subject to editorial revision and shortening.

The journal also publishes editorials which are normally specially commissioned. The Editor welcomes suggestions regarding suitable topics; those wishing to submit an editorial, however, should do so only after discussion with the Editor. 